\title{
Modern solidarity and administrative repression
}

\author{
Professor Dan Claudiu DĂNIȘOR ${ }^{1}$ \\ Associate professor Mădălina-Cristina DĂNIȘOR ${ }^{2}$
}

\begin{abstract}
Modern society is based on the predominance of organic solidarity over mechanical solidarity and, consequently, on the predominance of the law, which ensures cooperation between autonomous subjects from repressive law, which sanctions, through penalty, any deviation from the standards of the common conscience. Modern society is "civilized", i.e. it is firstly and foremost based on "civil" law, the repressive law only being exceptional, which translates into three principles: that of the subsidiarity of criminal law, that of the necessity and legality of offences and penalties, and that of the additional protection of individual freedom when the subject is criminally charged. The consequence thereof is that, in modern liberal democracies, all repressive law is criminal, that any charge which may lead to the application of a repressive sanction is a criminal charge and that the law-maker cannot assign to the administration the competence regarding the application of repressive sanctions. Under these circumstances, the transformation of some repressive norms into norms of administrative law is a violation of the fundamental principles that structure the legal order of modern liberal states. Nonetheless, this type of practice is becoming more common. In order to ensure individual freedom, this tendency must be corrected. As politicians are not willing to do so, naturally this is a task for the judicial courts, that can rely for this endeavour on the European Court of Human Rights' constructive jurisprudence.
\end{abstract}

Keywords: structure of judicial systems, rule of law, criminal law, administrative repression, administrative authorities, European Court of Human Rights.

JEL Classification: K10

DOI: $10.24818 / \mathrm{TBJ} / 2021 / 11 / 3.04$

\section{Mechanical solidarity, organic solidarity and the exceptional nature of criminal rules}

Collectivist societies have accustomed us to the idea that law protects the "social bond". We are inclined to accept this because it is easy to understand that people gather in social groups because they are alike, and these likenesses must be defended so that the group can survive. The alternative is harder to justify. It consists in stating that law defends the autonomy of the individual from the collective conscience and from the norms enacted on its behalf, that is, from "normality". There is a permanent conflict between the two forms of understanding law, but there is also

\footnotetext{
${ }^{1}$ Dan Claudiu Dănișor - University of Craiova, Fundamental Legal Research Centre, Romania, dcdanisor@yahoo.fr.

${ }^{2}$ Mădălina-Cristina Dănișor - University of Craiova, Fundamental Legal Research Centre, Romania, madalina.danisor@yahoo.com.
} 
a subtle complementarity. This is because social solidarity is shown to us in two forms, but it is unitary in nature. The two forms of solidarity are, if we follow the distinction made by Emile Durkheim, solidarity through similarity (or mechanical) and solidarity through the social division of labour (or organic) s $^{3}$. They combine in different proportions, leading to different forms of society and legal order.

The first form of social solidarity, the mechanical one, is involuntary. Durkheim calls this type of solidarity "mechanical" because it unites individuals into a whole only in so far as they fully comply with the requirements of the social body and do not have an autonomous behaviour: "The social molecules which can be coherent in this way can act together only in the measure that they have no actions of their own, as the molecules of inorganic bodies." ${ }^{4}$ Mechanical solidarity unites us in a society because we are alike: we have the same origin, the same race, the same traditions, etc. and we participate, due to these likenesses, in a "common conscience". People are people only if they join the group. The concept is very old. It was already known to Aristotle: "he who is unable to live in society, or who has no need because he is sufficient for himself, must be either a beast or a god: he is no part of a state" 5 .

In this type of understanding of the social group, there is no place for the autonomy of the individual. "The individual conscience, considered in this light, is a simple dependent upon the collective type and follows all of its movements, as the possessed object follows those of its owner. In societies where this type of solidarity is highly developed, the individual does not appear [...]. Individuality is something which the society possesses" 6 .

This type of instrumentalization of the individual by the group, of the full inclusion of man in the community, was practiced by primitive societies, but also by totalitarian regimes: the Nazis annulled so much the autonomy of individuals that they denied the very quality of legal subjects, replacing it with "standing-as-amember-of-the-community" (Glied-Sein) ${ }^{7}$, and the communists theorized that in their society "the concept of the individual as a legal subject [...] was replaced by the state enterprise and other public corporate entities as the principal subject of law" 8 . In these societies, whoever is not "like us" and does not comply with the requirements of collective conscience, social normality, cannot be a member of the group. He must be compelled, through punishments, to conform to the common conscience or, if it is not possible to obtain conformity, "integration", then

${ }^{3}$ Emile Durkheim, The Division of Labor In Society, trans. George Simpson (Illinois: The Free Press of Glencloe, 1960).

${ }^{4}$ Durkheim, The Division of Labor In Society, 130.

${ }^{5}$ Aristotle, Politics, trans. Benjamin Jowett (Kitchener: Batouche Books, 1999), 6.

${ }^{6}$ Durkheim, The Division of Labor In Society, 130.

${ }^{7}$ Olivier Jouanjan, "Justifier l'injustifiable" (Justifying the unjustifiable), Astérion, no. 4 (2006): 141-42.

${ }^{8}$ Evgeny Pashukanis, “A Course on Soviet Economic Law”, in Selected Writings on Marxism and Law, ed. Piers Beirne and Robert Sharler (London New York: Academic Press, 1980), 303. 
eliminated. Therefore, in societies based on solidarity due to resemblance "actions [...] have universally been regarded as criminal"9. The legal reaction of the community "proceeds from a quite mechanical reaction, from movements which are passionate and in great part non-reflective" 10 , through which society defends the common conscience, imperatively demanding that all individuals have the traits and behaviour which attach them directly and fully to the community. All types of behaviour contrary to the "most essential social likenesses" are "crimes", and their repression has the effect "the maintenance of the social cohesion which results from these likenesses" $" 11$.

Solidarity through the social division of labour, the other form of solidarity, unites people in a society because each contributes, while playing a different social part, to the satisfaction of everyone's needs. People gather because they are different. These differences make them complementary. This type of solidarity is mainly achieved in modern society, because this society "is possible only if each one has a sphere of action which is peculiar to him; that is, a personality. It is necessary, then, that the collective conscience leave open a part of the individual conscience in order that special functions may be established there, functions which it cannot regulate. The more this region is extended, the stronger is the cohesion which results from this solidarity." 12 Durkheim calls this type of solidarity "organic" because it resembles that established between the organs of superior animals: "Each organ, in effect, has its special physiognomy, its autonomy. And, moreover, the unity of the organism is as great as the individuation of the parts is more marked."13

\subsection{Subsidiarity of criminal law}

Criminal law, which constituted all law in primitive societies, regulates, with the prevalence of solidarity due to difference, only what directly attaches the individual to the common conscience. As a result, it becomes exceptional. Most individuals' behaviour is governed by rules which do not involve sanctioning by punishments. Since law must give the individual as wide a sphere of autonomy as possible (guaranteeing that he can retain his personality and, on the basis of specific differences, his own talents and skills, he can enter into cooperative relations, exchange of rights, with the others), legal rules must not be imperative, but permissive, supplementary or, at most, entail restitutive sanctions. These rules are the "civil" rules. Their function is to ensure cooperation between autonomous subjects.

The greater the autonomy of individuals, the greater their specialization, which results in increased social entropy. The social whole, like complex organisms, is all the more stable the more mobile its elements are, and the law that impedes this

\footnotetext{
${ }^{9}$ Durkheim, The Division of Labor In Society, 71.

${ }^{10}$ Durkheim, The Division of Labor In Society, 108.

${ }^{11}$ Durkheim, The Division of Labor In Society, 106.

${ }^{12}$ Durkheim, The Division of Labor In Society, 131.

${ }^{13}$ Durkheim, The Division of Labor In Society, 131.
} 
mobility in relation to the common, levelling conscience is less often used. Premodern society is like a sand castle: in order to stay in the required shape, the grains of sand must be welded together, for example by humidification. Modern society is like a sand dune: the grains of sand can be taken by the wind, having individual disordered movements, the dune can change its shape or position, but it remains a "dune". This stability through mobility is the great gain of the modern age.

The more autonomous individual personality is from the common conscience, ensuring the specialization of social roles, the more civil law, "cooperative" law, must regulate a greater part of the subjects' behaviour, and criminal law must be more restricted, it must be exceptional, it must be used only as ultima ratio ${ }^{14}$. In order to "defend" modern society, criminal law, which "welds" social molecules into a "common conscience", must be strictly delimited and classified.

This exceptional nature of the rules that punish has led moderns to adopt constitutions that establish the principles of the need for criminalization, legality of criminal offences and penalties and activation of special protection for those who are criminally charged.

\subsection{Principle of the need for criminalization}

For the moderns, freedom is inherent in human nature, and individual rights are constitutive of society. Therefore, they were declared by the French revolutionaries in 1789 , "the aim of any political association" 15 . Society no longer aims at the common conscience of the group, but at the autonomy of individuals, their freedoms and rights. The modern association is no longer a mechanical aggregation. It is voluntary and therefore "political". On behalf of this individualistic and voluntarist view of society, a new conception has been imposed on what can be defended through punishments that ensure compliance with the common conscience. As this common conscience no longer covers the whole human existence, and some aspects of social life must be located outside it, more and more behaviours must remain outside the possibility of criminalization. First, those concerning the exercise of political functions, since in modern societies "governmental [...] functions [...] are surely outside the common conscience" ${ }^{16}$. The exercise of constitutional competences cannot entail criminal liability, as the violation of their limits can only engage "political" liability. Secondly, the ideological, scientific or religious beliefs of individuals and possible conflicts due to them are outside the common conscience and therefore criminal law. The autonomy of individual conscience is guaranteed in modern societies precisely against the "normality" required by the common conscience. Any dispute that may arise as a result of its $a b$-normal exercise, if it has legal relevance, must be settled by the minimum necessary interference, which

\footnotetext{
14 Nicolas Queloz, "Le droit pénal comme ultima ratio: vraiment?", Review of Juridical Sciences, no. 2 (2013): 9-17.

${ }^{15}$ Art. 2 of The Declaration of the Rights of Man and of the Citizen of 1789.

${ }^{16}$ Durkheim, The Division of Labor In Society, 80.
} 
excludes criminalization. Thirdly, criminal law cannot impose morality, even if it is in the majority. Even with the endorsement of the majority, criminal law cannot disregard the morality of the minority. "We can therefore consider that the criminal rule, political by its source and coercive by its effects, does not constitute a priori, given its specific nature, the mandatory vehicle, often not even the most appropriate vehicle, of moral convictions, even if they are shared by the whole society" ${ }^{17}$. The acceptance of intervention under criminal law, most often passive, must be doubled by respect for necessity and proportionality, otherwise we risk facing the imposition of a moral order by force. And "when the moral order claims to be imposed by force, even by the force of the law, it risks arousing a state of mind hostile to law and virtue, which is a prejudice to both morality and legality" ${ }^{18}$. Criminal law must be based only on a minimum morality, one that can be intuitively held to be true regardless of the nuances of the various moral beliefs present in society at a given time. "The idea of a moral minimum [...] explains how it is that we come together; it warrants our separation. [...] The morality in which the moral minimum is embedded [...] is the only full-blooded morality we can ever have"19. Therefore, "crimes" can only be behaviour contrary to the "most essential social likenesses", which in the modern era can only be the likenesses resulting from the moral minimum, which lies at the crossroad of all our moral doctrines. They are the only ones that can entail punishments, i.e. sanctions which have "the effect the maintenance of the social cohesion which results from these likenesses" ${ }^{20}$.

In a society that aims to protect the rights of individuals, the role of criminal law is neither obvious nor indisputable. "Contrary to a current bias, unfortunately often shared by the contemporary legislature, the qualification of any conduct under criminal law should not be considered a priori as obvious or 'natural'."21 On the contrary, criminalization, and therefore penalties for non-compliance with the requirements of the common conscience, must be "strictly and evidently necessary" ${ }^{\prime 2}$. Their purpose is, like the purpose of any political association, to protect the rights and guarantee the autonomy of individuals. Even if this goal is achieved indirectly, by defending the various forms of order, these "orders" are never goals, but only tools to achieve the goal of any political association: guaranteeing the natural and inalienable human rights. So the "legislature" cannot criminalize everything. The legality of criminal offences and penalties is not enough to guarantee the autonomy of individuals and the rights in which it is transposed. It is only an

\footnotetext{
17 Michel Van de Kerchove, "Pour une étique de l'intervention du droit pénal, entre moralisme et instrumentalisme", in Variations sur l'éthique. Hommage à J. Dabin, ed. Hélène Ackermans (Bruxelles : Presses de l'Université Saint-Louis, 1994), 459.

18 Jean Dabin, Théorie générale du droit (Paris : Dalloz, 1969), 382.

${ }^{19}$ Michael Walzer, Thick and Thin. The Moral Argument at Home and Abroad (London: University of Notre Dame Press, 1994), 11.

${ }^{20}$ Durkheim, The Division of Labor In Society, 106.

${ }^{21}$ Van de Kerchove, "Pour une étique de l'intervention du droit pénal, entre moralisme et instrumentalisme", 449.

${ }^{22}$ Art. 8 of the Declaration of the Rights of Man and of the Citizen of 1789.
} 
instrument for properly structuring one of the "orders": legal order. An important one, but which, if not backed by the limitation of the legislature itself, does not actually solve the problem.

\subsection{Principle of the legality of offences}

In modern societies, penalizing behaviour can only be done by law. The principle requires the existence of a formal normative act, adopted by the body representing the people, which establishes the acts that constitute offences. In the absence of this formal provision, the offence does not exist (nullum crimen sine lege) and no repressive sanction, punishment, can be applied (nulla poena sine lege). The law cannot, of course, establish other penalties than those "strictly and evidently necessary" ${ }^{23}$. The fact that only the people's representatives are the ones who can determine what behaviour constitutes crimes and what punishments can be applied to those who adopt it reflects the primitive nature of criminal liability, the fact that resorting to it, even if necessary, involves a risk of barbarism, of lack of "civilization", deviation from humanism. The moderns have thus become aware of the fact that criminal justice must be done by the whole people ${ }^{24}$ and that where its dimensions do not allow it, only the people's representatives can do it. Upstream, by establishing the offences only by its representatives; downstream, by finding the guilt of having violated the rules of the common conscience only by those who represent the people in criminal proceedings: the jurors. The protection comes from the fact that state administrations are excluded from the criminal decision-making process. They can only assist the people technically.

In the modern era, "the legality of criminalization and punishment appears as one of the most important limitations of ius puniendi, as it represents the main guarantee of the legal certainty of the citizen before criminal law"25. Its imposition as a guiding principle of criminal law represented the triumph of the foreseeable law over the arbitrariness of state administration. "Moreover, the principle of the legality of penalties is the depository of the ideal of 'retained justice' intended to protect the citizen and his freedoms against the Sovereign's power to punish" 26 . It signifies the separation from the feudal system, in which there was a "master" who had the right to punish. In modern societies there is no master. People have taken destiny into their own hands, they have habeas corpus, they are their own masters, that is, they are autonomous (from auto and nomos), they themselves establish what is normal.

${ }^{23}$ Art. 8 of the Declaration of the Rights of Man and of the Citizen of 1789.

24 "In primitive societies, where, as we shall see, law is wholly penal, it is the assembly of the people which renders justice": Durkheim, The Division of Labor In Society, 76.

${ }^{25}$ Yves Cartuyvels, "Les paradigmes du droit pénal moderne en période «post-moderne» : évolutions et transformations", in Un droit pénal postmoderne? Mise en perspectives des évolutions et ruptures contemporaines, ed. Michel Massé; Jean-Paul Jean; André Giudicelli (Paris : Presses Universitaires de France, 2009), 7, https://dial.uclouvain.be.

${ }^{26}$ Yves Cartuyvels, "Les paradigmes du droit pénal moderne en période «post-moderne» : évolutions et transformations", 7. 


\subsection{Protection against criminal charges as the first protection of the subjects' autonomy}

In modern societies, the first form of individual legal autonomy, and therefore of legal certainty of the person, is the autonomy from the common conscience and, consequently, from criminal law. In the Middle Ages, "until the war of religions, [...] any political power is defined as the exercise of a judicial function" 27 . The modern theory of the separation of powers in the state opposes this idea, trying to make legislation autonomous from justice. That is why for Montesquieu the central idea was that of transforming the judiciary into a «somewhat null» ${ }^{28}$ power, of course, from a political point of view, that is, from the point of view of legislation. But in the early days of modernity, the separation of powers was conceived the other way round: as a process of rendering justice autonomous from legislation: "The first theory of the separation of powers in the state was invented, during the first English revolution, to resist the tyranny of the Long Parliament, between 1645 and 1650. [...] But this principle of the separation of powers had a profoundly different content from its contemporary significance: it was not at all a question of forbidding parliament from intervening in matters of government, but of shielding the functioning of ordinary justice from any parliamentary intervention. The radical levellers, persecuted by the Presbyterian majority, tried to prohibit any intervention of the law-maker in the legal proceedings against them, so as to benefit from the guarantees of the common law. [...] During the 1640s, the central notions of legality and non-retroactivity of crimes and penalties take shape. [...] It is precisely by extrapolating the principle of the legality of criminal offences and penalties that the opponents of the levellers come to enunciate the first theory of the separation of powers." 29

The legality of criminal offences and penalties is not a guarantee of individual freedom, among other things, but is central to the very definition of freedom. The freedom of the moderns differs from the freedom in ancient societies in that it is understood as a right, and this right is defined primarily by reference to the criminal rules and punishments established by them. As Benjamin Constant wrote, freedom "for each of them [...] is the right to be subjected only to the laws and to be neither arrested, detained, put to death or maltreated in any why by the arbitrary will of one or more individuals" ${ }^{\prime 3}$. Just because the law that imposes similarities is subsidiary, cooperation between different, autonomous individuals can expand and society can progress through the use of each other's talents. Modern

${ }^{27}$ Carlos Miguel Pimentel, "Le sanctuaire vide: la séparation des pouvoirs comme superstition juridique?", Pouvoirs 3, no. 102 (2002): 123.

${ }^{28}$ Montesquieu, L'Esprit des Lois, Livre XI, Chapitre VI.

29 Carlos Miguel Pimentel, "Le sanctuaire vide: la séparation des pouvoirs comme superstition juridique?", 122.

${ }^{30}$ Excerpt from: Benjamin Constant, "The Liberty of the Ancients compared with that of the Moderns", in Political Writings, trans. and ed. Biancamaria Fontana (Cambridge: Cambridge University Press), 310. 
society is thus a "civil" society, i.e. a society in which order results from the free exercise of rights, governed by non-repressive, civil rules.

The legal regime for arranging the exercise of individual rights and freedoms is, in this society, the repressive regime, one in which the state allows subjects to exercise their rights freely and represses, only post factum, abuses affecting the common conscience, provided that they are legally established in advance, by exceptional criminal rules. The procedure for the application of these criminal rules must therefore fulfil two functions: that of ensuring the application of the criminal rules (and thus the effective conduct of criminal instruction) and that of safeguarding individual autonomy from the common conscience (and thus ensuring the protection of individual freedom during this criminal instruction).

Whenever an accusation, which may lead to a punishment, is brought against an individual, special protection is activated for his benefit. This presupposes, pursuant to art. 6 of the European Convention on Human Rights, that everyone has the "right to a fair trial". This involves extensive guarantees regarding the establishment of the court, the independence and impartiality of judges, the duration and quality of the trial and the rights of the accused person during the proceedings, especially as regards his defence. Any person charged with a criminal offence shall be presumed innocent until definitively proved guilty.

Only the subsidiary character of criminal law and of the punishments to which the criminal charge can lead and the bivalent character of criminal proceedings allow modern society to be based on individual freedom, a freedom understood as a right to autonomy, even as a right to difference. In this society, to impose uniformity on behalf of the common conscience, when it is not natural, is an injustice.

\section{The place of administrative law in the system of modern law}

The fundamental legal dichotomy which characterizes modern law is, as resulting from the above analysis, that between criminal law and civil law. The more "civilized" a society is, the more important civil law is within the body of legal rules, to the detriment of criminal law, which becomes subsidiary.

The question that this study requires is "What is the place of administrative law in this society?". The answer to this question has produced a split in modern European legal cultures. The first option, outlined in English law, involves denying the need for administrative law if it is understood as derogating from the general regulatory framework, which gives the state a privileged status over other legal subjects. In this view, the legal order uniformly subordinates all its subjects and, consequently, the state is subject to the legal order like any other subject. Some English authors have even argued that one of the peculiarities of the English theory of government is that it "does not use the notion of state at all" 31 or that it does not

${ }^{31}$ Maurice Amos, La Constitution anglaise, trans. Paul de La Pradelle (Paris : Sirey, 1935), 113, apud F.H. Lawson, "Le droit administratif anglais", Revue internationale de droit comparé 3, no. 3 (1951) : 413. 
use the notion of state in a specialized legal sense, "i.e. it does not consider the English state a legal person", replacing it, with regard to central public authorities, with the notion of "Crown", which "embodies only the whole nation" and comprises only the royal administration ("The King's Government"), namely the ministries and other institutions of the same nature, and with regard to local authorities, considering that they "are independent legal persons, which do not differ significantly from private companies" and that "they are not the emanations of the Crown [of the state, if we were to translate it into the continental legal language; our note] and have never enjoyed the special privileges the former enjoys", as they are always subject to the control of the courts in accordance with the rules of the common law ${ }^{32}$.

So it is administrative law in the sense that the matters governed by it are distinct from those governed in the European continental law by private law, but "there is no distinction in principle between the powers of an official under a law and those which an employer has with regard to his employees by virtue of an employment contract. Even for the man in the street, the exercise of public power will be on an equal footing with the exercise of power created by an act of private law"33. Administrative law is, therefore, distinct from civil law only in terms of matters, not principles, and concerns only "secondary normative acts, in the form of regulations, etc., and the two parts of administrative litigation, whose object is the imposition of contractual and extra-contractual civil liability of public authorities and the exercise of judicial control over these authorities, through certain appeals that resemble the appeal for excess of power and other appeals that are used before the Council of State" 34 in the French system. For English lawyers, there is no distinction, classic in European continental law, between private law and public law. It is rejected because it reflects "the manifestation of the idea that the state and the administration would not be subject to the law" 35 . The existence of administrative law which has principles differing from those of civil law is thus contrary to the rule of law as understood in this cultural space.

American law retains the English reluctance to remove the state from the control of ordinary jurisdictions, which is strengthened by the establishment, in addition to the control of administrative acts, of the judicial control of the constitutionality of laws. There is administrative law, but it does not privilege the state. It is a new branch of law, which has a half-administrative, half-judicial character, like the old equity, and is developed and administered by independent bodies, the agencies, which also have regulatory functions, serving to introduce new "laws", in areas that require particular specialization, especially in the economic and social field, laws that could not be introduced through the traditional mechanisms of producing legal rules in the American system. These agencies also have some

${ }^{32}$ F.H. Lawson, "Le droit administratif anglais", Revue internationale de droit comparé 3, no. $3(1951): 413$.

${ }^{33}$ F.H. Lawson, "Le droit administratif anglais", 413.

${ }^{34}$ F.H. Lawson, "Le droit administratif anglais", 412.

${ }^{35}$ René David, Camille Jauffret-Spinosi, Les grands systèmes de droit contemporains (Paris : Dalloz, 2016), § 289. 
jurisdictional functions, serving to reduce the number of cases brought before the courts. But these agencies always operate under the control of traditional courts.

The other answer to the question regarding the position of administrative law in the modern legal system involves the separation of administrative law from the general regulatory framework, civil law, and its transformation into derogating law, applicable to the state and its relations with other legal subjects. By establishing this administrative law, the state builds a privileged legal regime, which aims to remove the administration (or at least a significant part of its activity) from the scope of common rules and, usually, from the jurisdiction of ordinary judges. Some mechanisms of internal control of administrative action are established through officials who progressively acquire a status similar to that of judges, but the judicial (or quasi-judicial) control of the administration cannot concern the appropriateness of its actions, and the control of administrative acts involves many exceptions. Administrative law is endowed with "its own system of sources, from which emanate rules that align with respect to each other and are, applicable, to the exclusion of any other, at least a part of administrative action" 36 . The recourse to such administrative law presupposes "a high level of civic spirit. It is conceivable only if the public opinion demands that the governors and administrators be subject to discipline and control and presupposes that the administrators see in the administered ones citizens, not subjects" 37 .

The two legal cultures have produced two distinct variants of relations between state and law. In the Anglo-Saxon area these relations are synthesized in the concept of "Rule of law", and in continental Europe in the concept of (literally) "state of law". The difference between the two concepts is that the former does not include the idea of state. "Rule of law" means a way of protecting the rights of the subjects, even against the state, while the "state of law" means a way of structuring the state, in order to achieve an intrinsic limitation of it and, indirectly, a protection of the rights of the subjects. The "Rule of law" implies the pre-existence of private rights as a foundation of the public space. Fundamental rights are not built in this system to guarantee that a certain private space, of freedom, is preserved, in opposition to a public space that is dominated by political power, but they are the very essence of the public, political space. Therefore, in the regime characterized as "rule of law" there is no difference that the statists (aware or not of their statism) make between public law and private law, because the state is subject to the same legal and jurisdictional regime as individuals. In this regime, it is not only about the fact that there is a part of the law which the state cannot reach and which thus is imposed on it, but about the fact that the state can never remove itself from the power of the law which it applies to its subjects, the general regulatory framework, civil law, by building a public law that privileges it over them. The supremacy of the law is thus

\footnotetext{
${ }^{36}$ Yves Gaudemet, Sophie Gaudemet, "Editorial", Henri Capitant Law Review Public Law, Private Law, no. 5 (30 December 2012): $§ 6$.

${ }^{37}$ René David, Camille Jauffret-Spinosi, Les grands systèmes de droit contemporains, $§ 70$.
} 
absolute in the regime characterized as the "rule of law" ${ }^{38}$. The rights of the subjects of the legal order are protected by judges whose impartiality towards the state is guaranteed primarily by the impossibility of an administrative law regime and by the fact that they judge the state like any other subject of the legal order.

The "state of law" as understood in continental Europe involves, on the other hand, a "well-ordered administrative state of law"39. In European continental culture, only the evolution of the democratic political system could lead to the gradual imposition of a state of law as a political standard, that is, as a teleological limit to the power of the state itself. However, the means of this limitation are structural, internal to the state. From the parliamentary state of law to the social state of law, the evolution of the European public state of law follows the evolution of democracy, i.e. the way in which political power is exercised. Political power is what defines and promotes the state of law, not the state of law is what defines politics. Democracy is not perceived in this legal space as an arrangement of the coexistence of the rights of the subjects pertaining to a legal order, through which a demos is constituted, but as an exercise, legitimized by the people, of the state power. This is because political society absorbs civil society, and public law is instinctively considered "superior" to private law. The consequence is that the state of law, as a jurisdictional balance of rights based on non-imperative, civil rules, as a state of justice, is replaced by a state governed by public law, which regulates power through a special, administrative law.

This conception is due to the development of a special theory of sovereignty, especially by Jean Bodin. Unlike Roman law, which considered that "merum imperium and the right to prosecute crimes punishable by the capital punishment belong to the magistrate, for Bodin, it belongs exclusively to the sovereign. Imperial jurists define magistracy through the activity of justice, Bodin defines it through the exercise of authority. From the inflections that Jean Bodin applies to the doctrine of the imperium to build the theory of sovereignty, results a certain number of characteristics of our state, marked by the importance of administration to the detriment of justice" ${ }^{40}$. The state of law resulting from the doctrine of sovereignty is thus necessarily an "administrative regime", one in which, regardless of the progress of the protection of rights through justice, the state remains "superior" to other legal subjects and "escapes" ordinary justice, building a special administrative law, distinct from civil law, applicable to individuals. Institutionally speaking, this type of state of law is characterized by the separation of authority from jurisdiction, the

38 Albert Venn Dicey, Introduction to the Study of the Law of the Constitution (London: MacMillian, 1939, $9^{\text {th }}$ edition), 188 sq. Dicey distinguishes the Rule of Law, a principle which he considers to be specifically English, from the French regime of administrative law, based on the pre-eminence of the state and the separation of powers.

${ }^{39}$ O. Meyer, apud Olivier Jouanjan, Figures de l'Etat de droit. Le Rechtsstaat dans l'histoire intellectuelle et constitutionnelle de l'Allemagne (Strasbourg : Presses Universitaires de Strasbourg, 2001), 33.

40 Blandine Barret-Kriegel, "Jean Bodin et la naissance de l'Etat administrative" in Les chemins de l'État (Paris : Calmann-Lévy, 2014), epub. 
latter losing both legislative competence and that of judging state administrations according to the common procedure, namely to reduce the state to the quality of subject to the legal rules created by justice itself. As Blandine Barret-Kriegel rightly noted, in Bodin's construction of the theory of sovereignty "there is a gain and a deficit. Because from the promotion of the administrative state to the detriment of the state of justice, which is the structural feature of our public power, results [...] this double definition of citizenship through sovereignty and of public office through authority. We will gain by this the fact that we escape the dispersion of feudal justice and the questioning of the hierarchical and inegalitarian idea of Aristotelian natural law, which are the remnants of the Empire, but we will lose judicial decentralization, jurisprudential equity, experimental fabrication of law, which are the wings of England. [...] The quintessential political act will be a decision of the authority. The general will will prevail over the jurisprudential agreement. We will lose confidence in justice." ${ }^{41}$ Even if the evolution of the European rule of law involves a phase described as a "jurisdictional state of law", this "state of law" is not a "state of justice"; it remains an "administrative" regime. This type of regime is continuously present in continental Europe against the background of the evolution of democracy, to which it "will be difficult [...] to avoid the ways of the state"42 and become an organization of rights and the people itself, not of political power.

There is a convergence movement of the two types of Western legal systems, but it is not very clearly defined. To complete it, the relationship between democracy and the rule of law should be rethought, by transforming the latter into a political standard for the protection of freedoms and rights that is binding on political power, even if it is democratic. The sharpest variant of evolution would be the one in which administrative law, as law that privileges the state, disappears. The variant that is widely practiced today is that of autonomous administrative authorities, which are endowed with regulatory, control powers and, increasingly, repressive and quasijudicial powers, which are taken out of the control of the political power and especially of the executive power, to apply some "objective" laws of social relations, which the power resulting from the will of the people should not be able to change. A new "natural" law is thus established, the knowledge and application of which is the prerogative of some new "pontiffs": the experts. They populate new structures of the state, which are neither administrations, nor jurisdictions, nor legislatures, but which exercise competences that traditionally belong to these powers.

\section{The evolution of the relations between criminal law and administrative law}

There are, therefore, two variants of structuring Western legal orders: the one in which the fundamental dichotomy is between civil law and criminal law and the one in which it is between civil law and administrative law. The first structuring

${ }^{41}$ Blandine Barret-Kriegel, "Jean Bodin et la naissance de l'Etat administrative", epub.
${ }^{42}$ Blandine Barret-Kriegel, "Jean Bodin et la naissance de l'Etat administrative", epub. 
variant denotes the preponderance of liberal philosophies in society, i.e. those for which individual rights and freedoms are constitutive of political society, their protection being its purpose, and in which, as John Rawls said, a basic freedom cannot be limited or refused except to protect one or more other basic freedoms and never $[\ldots]$ in the name of the public good or perfectionist values ${ }^{43}$. The second variant of structuring denotes the preponderance of collectivist philosophies in society, i.e. those in which fundamental choices are made by the political power, in the name of the common good and perfectionist values, to achieve the good society for the community. In order to achieve this, the state must be able to obtain everyone's compliance with the rules (which it creates or discovers in the nature of social things through experts) by which it projects (or lets project itself) the good society. These rules may restrict the exercise of individual rights and freedoms precisely in the name of the common good or perfectionist values, a type of restriction which was excluded in the first version of the system. Cooperation between individuals no longer results, in this type of understanding, mainly from the differences between them, which make them have to trade rights to meet their needs, but from the adherence of all to a community ideology. It is imposed on behalf of a general interest above individual interests (of the state, of markets, etc.). The legal expression of this common interest is administrative, state or autonomous law.

This establishes a new type of "common conscience": an ideological one. Society tends to obtain the conformity of individuals to a politically determined project, through public, administrative law, which takes over part of the function that criminal law performed in liberal societies, that of sanctioning by penalties individual drifts from the requirements of the common conscience. This evolution is more visible in totalitarian regimes, but it is present in all Western political regimes. In the totalitarian societies of the last century, as Raymond Aron wrote, since any activity will henceforth become a state activity and since any activity will be subject to ideology, a mistake made in an economic or professional activity is simultaneously an ideological mistake. Hence, of course, a politicization, an ideological transfiguration of all possible mistakes of individuals and, in conclusion, a terror that is equally police-related [administrative] and ideological ${ }^{44}$. This transfiguration is present in all political regimes based on the distinction of administrative law from civil law, even if it is more masked than in totalitarian regimes. It is transposed, from the point of view of the structure of legal order, into the existence of administrative repression.

\section{The tendency to turn repression into an administrative competence}

In modern liberal societies, where organic solidarity prevails, "governmental $[\ldots]$ functions $[\ldots]$ are surely outside the common conscience" 45 . Administrative law,

43 John Rawls, Libéralisme politique (Paris : Presses Universitaires de France, Quadrige, 2007), 351.

${ }^{44}$ Raymond Aron, Democraţie şi totalitarism (Bucureşti: All, 2001), 212-13.

${ }^{45}$ Durkheim, The Division of Labor In Society, 80. 
the legal expression of these functions, cannot, as a consequence, be repressive, because repression can only be instituted to defend what is intrinsic to the common conscience. Administrative law is, in these societies, fundamentally different from criminal law. It can never contain rules whose sanction is repressive and dissuasive. In the liberal view, the rule of law is therefore necessarily a "state of justice", not an "administrative state". In this type of state, as John Rawls argued, "the rights secured by justice are not subject to political bargaining or to the calculus of social interests" ${ }^{46}$, i.e. of the restriction by state administrations in the name of a common good above the good of individuals and defined by the political power in the name of the common conscience.

Unfortunately, the liberal understanding of the relations between criminal law and administrative law is today a minority in the Western legal space. As a result, administrative law regulates an increasingly important part of repression. This translates into the establishment of repression that is increasingly managed by state administrations, autonomous or directly subordinated to the political, and not by a judge that is independent of the political powers of the state.

The first sign of administrative repression is the transformation of state bodies that instrumentalize criminal charges in administrative or quasiadministrative bodies. For this reason, in all the countries of continental Europe, the status of the Public Ministry is a mixed status. Prosecutors are in a middle position between the executive and the judiciary ${ }^{47}$. "At the level of the member countries of the Council of Europe, all public ministries have a common feature: they are the outcome of a hierarchical pyramid organization headed, as the case may be, by an Attorney General subordinated to the minister (Spain, Finland, Hungary, Norway, Portugal, Romania), a College of Attorneys General (Netherlands, Belgium), or the Minister of Justice (Germany, Austria, France, Poland). Depending on the degree of autonomy of the hierarchy, public ministries may be the addressees of instructions issued by the executive branch" 48 . "In practice, given the variety of European systems, the guarantee of independence varies depending on the organic link woven by the Constitution or the law between the public ministry and the executive power" 49 . Thus, the solutions vary "from total independence to total subordination, passing through a multitude of intermediate forms, as diverse and original as they are less enlightening for the construction of a system of generally applicable principles" $"$. One thing is clear, however: those who instrumentalize criminal

${ }^{46}$ John Rawls, A Theory of Justice (Cambridge, Massachuttes: The Belknap Press of Harvard University Press, 1971), 4.

47 Dan Claudiu Dănişor, Mădălina Cristina Dănişor, "Restructurarea justiției și statutul procurorilor", Curierul Judiciar, no. 5 (2018): 245-50.

48 Denis Salas, Philip Milburn, "Les procureurs de la République. De la compétence personnelle à l'identité collective", Archives de politique criminelle 29, no. 1 (2007) : 102.

49 Denis Salas, Philip Milburn, "Les procureurs de la République. De la compétence personnelle à l'identité collective", 102 .

${ }^{50}$ Horia Diaconescu, Dan Claudiu Dănişor, "Poziţia ministerului public faţă de puterea executivă în dreptul unor state vest-europene și în România”, Dreptul, no. 5 (2006) : 102. 
charges are (in one way or another and to varying degrees, but certainly) placed in the sphere of action of the executive branch and in the area of regulation of administrative law. The latter acquires influence on criminal repression which the systems based on liberal philosophy and on the strict interpretation of the separation of powers exclude as a matter of principle. We will not analyze this form of administrative repression here, because we did it on another occasion ${ }^{51}$.

The second sign of administrative repression is the empowerment of some administrations to establish, through normative acts adopted on the basis of their regulatory autonomy, repressive sanctions, punishments. Administrations which, in the liberal view of the legal-parliamentary state, can never establish such sanctions, as they are in the exclusive competence of the legislature, can now participate in the regulation of repression. In terms of the evolution of the rule of law, we move from the parliamentary rule of law (whose central figure was the representative and which, from the point of view of the structure of legal order, involved a normative hierarchy in which administrative acts could not have a normative character) to the administrative rule of law. This second type of rule of law ${ }^{52}$ corresponds to the second phase of the evolution of modern democracy, in which instrumental reason, the official, the executive and the administrations, are the central element of public power. In this type of state goverened by the rule of law, the priority given to the executive and administrations, due to the efficiency of administrative action as opposed to the slowness and inefficiency of parliaments, makes a regulatory area pertain to the law and the general regulatory power return, de jure or de facto, to the executive. Therefore, the administration is strictly and legislatively classified only in certain domains, in others it is either legally empowered or allowed to act normatively on its own initiative. Parliaments retain a right to control this administrative regulation, but this right is to a great extent illusory. The relations between the state and its citizens are "administrative", which means that the relations are "concrete", not "abstract" 53 , as in the legal-parliamentary system, and the parties to these "concrete" legal relations are no longer on an equal footing, as in the ordinary law, but the administration subordinates the other subject. As the Romanian Constitutional Court states, "the constitutional provision [which regulates the fundamental right to equality] refers to equality between citizens, and not to the equality of the citizens with the state authorities" ${ }^{24}$. In translation, this means that people have become, as before modern times, "subjects" instead of "citizens".

The third sign of administrative repression is the creation of autonomous administrative authorities that combine some functions of repressive sanctioning

51 Dan Claudiu Dănișor, Mădălina-Cristina Dănișor, "Restructurarea justiției și statutul procurorilor", 245-50.

52 See for details Dan Claudiu Dănișor, Modernitate, liberalism şi drepturile omului (Craiova: Simbol, 2018), 244-48 and the works cited there.

53 On the relations between concrete order and abstract order, see Dan Claudiu Dănişor, Mădălina-Cristina Dănișor, "Totalitarianisms and the establishment of objective legal order", Juridical Tribune 10, no. 1 (March 2020): 36-55.

54 “Decision no. 225/1999”, Official Gazette no. 126 (21 February 2000). 
with the functions of regulation and control. This type of authorities make their presence felt in all contemporary constitutional systems, under various names: in the United Kingdom, Non-departmental Public Bodies or Quasi Autonomous nongovernmental Organizations (Quangos), in the United States, Independent Regulatory Agencies, in France, Autorités administratives indépendantes ${ }^{55}$, etc. In Romania, the Constitution regulates them under the generic name of "autonomous administrative authorities" $" 56$. Regardless of their name, the function of these authorities $^{57}$ is "the development of a sector of social life, through the effort to ensure certain balances" 58 , apart from the political (irrational?!) choices of individuals and the structures that frame their expression, especially political parties, on the basis of some "objective" laws of social development.

\section{Violation of individual freedom by administrative repression}

The apparent reasons for administrative repression are related to speed and specialization. Parliaments are too slow, and so is justice. Therefore, the administrations are the ones called to satisfy the need for speed, which has sometimes become pathological in our societies. In order to do so, they must be given functions that were normally entrusted to our representatives, parliamentarians, or the guarantors of our rights, judges. Among them, a privileged function is that of repression through punishments. The transfer is due to the apparent inadequacy of the political (and therefore "subjective") nature of the representation with the "regulation" of certain social mechanisms that seem to be "objective" and the judicial criminal proceedings, too slow due to the multiple procedural guarantees offered to criminal defendants, with the phenomenon of the more and more massive involvement of state administrations in the regulation of socio-economic relations. Translated into more direct language, these phenomena mean that society comes across our political freedom and cannot develop independently of us - "objectively" - and that the state cannot dominate society as it pleases because it has to face the protection of our human rights and freedoms, triggered by our criminal charge. The simplest solution is to formally remove the accusation from the sphere of criminal law and to reclassify it as administrative, so that it can be regulated not by political authorities, but by experts. In this way, the autonomy of the persons no longer hinders the speed of action of the public power and the general interest defined by it. Another reason invoked to justify this administrative repression is the increasing technicality of economic and social mechanisms, a complexity that goes beyond the

55 Pierre Rosanvallon, La Légitimité démocratique. Impartialité, réflexivité, proximité (Paris: Seuil, 2008), 121.

56 See George Liviu Gîrleșteanu, Drept constituțional și instituții politice, (București : Universul Juridic, 2012), 272-77.

${ }^{57}$ For an overview in Romanian law, see George Liviu Gârleșteanu, Autorități administrative autonome, (București : Universul Juridic, 2011).

58 Jacques Chevallier, "Réflexions sur l'institution des autorités administratives indépendantes", La Semaine juridique, Juris-classeur périodique, no. 30-32 (6 août 1986, I.3254) : [8]. 
intellectual powers (lacking nuances) of politicians and judges. Translated, this second argument would sound like this: instead of educating politicians and judges so that they can better understand economic and social phenomena, we keep them ignorant, in order to transfer some of their natural competences to some administrators, who, of course, must, in turn, be specialized. The logic is obviously crooked! But the reality is that all countries have multiplied their autonomous regulatory authorities and repressive administrative sanctions to remedy these "inadequacies" of political representation and criminal repression ${ }^{59}$.

Public opinion, fearful of the unscrupulousness of politicians and of criminal repression, has the impression that the "objectification" of a regulation, by transferring it to the experts of autonomous administrative authorities and decriminalizing behaviour, to be regulated by administrative repressive sanctions, is a progress. In fact, these two mechanisms are used extensively to violate fundamental freedoms and rights.

\subsection{Violation of political freedom by establishing autonomous administrative authorities}

Modern man has freed himself from feudalism, of course, but also from divinity and from objective or quasi-objective determinations ${ }^{60}$. It is the first time in history when the individual claims to decide on his own fate, that is, to choose. The social expression of this new capacity is political freedom. Modernity centres everything around this type of freedom: all fundamental decision-making processes are the institutional consequences of this freedom, and all legal rules are based on people's free political choices. All the mechanisms of modern constitutionalism aim at limiting the tendency of social processes to become autonomous of individuals and, therefore, to elude their political freedom.

In this logic of things, there are no "natural" or "objective" social laws. All social laws are human, based on the political freedom of people, that is, in the final analysis, on their liberation from polis and from the common conscience. The laws of the city are based on social policy, resulting from the free choices of people, not from any social science, which would describe the "objective" laws of the city. The basic assumption of this conception is that man is able to be free and decide for himself. It is obviously an optimistic view.

To some, more and more, this optimism seems unrealistic. People cannot and often do not even want to decide their own fate. They do not make rational choices, and the mechanisms based on the choices they make can only lead to incompetence and to crises. Politicians, dependent on people's political choices, based on emotions, do not seek to build a better society, but to be re-elected. They

${ }^{59}$ Emmanuel Rosenfeld, Jean Veil, "Sanctions administratives, sanctions pénales", Pouvoirs, no. 1 (2009) : 61-73.

60 This section of the article reproduces some of the considerations from Dan Claudiu Dănişor, "The Expert or the People? - On the Justification of Autonomus Authorities", Revista de Ştiinţe politice/Revues des sciences politique 57 (2018) : 13-24. 
cannot afford to be rational and base their decisions on scientifically sound laws. Democracy is a mechanism of self-destruction with delayed programming. The logical consequence is that certain social mechanisms, the most delicate, fundamental, must be removed from the influence of people's political choices and must rely on the objective laws of society, which only the holders of scientific competences can know. These "experts" are the ones who must be drawn into "autonomous" authorities in relation to our political choices and to whom we must yield the regulation of fundamental social issues.

The problem is that this shift from politics to scientific expertise takes us back in time. Modern man, who had taken his destiny into his own hands, building his own laws only on the basis of his free choices, is again subject to laws he cannot control, which are imposed on him, this time, in the name of Science. Politics is, in this view, suspicious, because it is irrational, that is, based on subjective choices and not on objective laws. So, we have to depoliticize. That is, to deprive ourselves of political freedom. Politicians, as a result of expressing this freedom, must give way to experts, who base their decisions on objectively acquired and proven competences, not on the irrational choices of people subject to the contingent who pursue only their own interests.

Depoliticization, however, means that modern man has surrendered. $\mathrm{He}$ wants to be led by experts - a kind of modern replacement for Plato's philosophers. We do not give up political power in this way, we "neutralize" it. It is clear that an expert is neutral. So let's not imagine a Leviathan. These are just apolitical, autonomous, expert-populated authorities which regulate social processes - that is, regulate, supervise, balance, and sometimes sanction - outside the modern chain of democratic legitimacy. When these authorities acquire the power to establish and apply repressive sanctions, it means that we can be punished without our representatives establishing, by law, the punishments, based on objective laws, discovered by experts in the nature of things. No matter how hard one tries not to think, it is clear that repression is done in violation of the legality of penalties, which, as we have seen, necessarily presupposes that they can be instituted only by the body resulting from our choices, from the expression of our political freedom.

Of course, there is a tendency to unify the two forms of repression, by the penetration of the guarantees of criminal proceedings in the procedure used for administrative repression, but this penetration only partially solves the problem. There remain, as we have seen, two very important objections to administrative repression: 1) it repressively sanctions behaviour other than that required for compliance with the minimum moral conscience of the community, and 2) autonomous administrative authorities that may impose repressive sanctions are outside the chain of legitimacy of public power through political freedom, hardly gained by modern man and outside the system of guarantees offered by the constitutionalism based on this freedom, without other guarantees being actually created. 


\subsection{Decriminalization and elusion or diminution of procedural protections}

If decriminalization meant the transfer of the regulation of social processes or behaviours to cooperative law, which uses only reparative sanctions, then it would be a sign of modernization and liberalization. But this is only rarely the case. In most cases, it is only a matter of removing repression from the sphere of criminal law and turning it into administrative repression. The individual is still "accused", changing only the accuser: instead of the people or the judge, it is the administration that plays this part.

However, it is no less dangerous to be accused administratively than criminally because, although administrative sanctions are increasingly invasive in the field of fundamental rights, individual's political, institutional and procedural guarantees are diminished as compared to those provided in the case of criminal charges. It is true then that excessive penalties, which take us back to the situation of "primitive" or "totalitarian" societies, should lead to decriminalization, but if, unfortunately, decriminalization is not followed by liberalization, there is no reduction in the real level of repression.

Administrative repressive sanctions are pecuniary (in Romania custodial administrative sanctions were prohibited only by the 2003 constitutional revision). Their classification as administrative ensures the flexibility of the application, by the fact that, although sometimes they are obviously repressive, the guarantees of criminal procedure do not apply to the one who will suffer the sanction, or do not fully apply. Thus, "jurisprudence admits that the guarantees specific to the repressive procedure are granted only at the stage of first or second appeals. In its initial phase, the sanctioning procedure used by an administrative authority may not fully meet the requirements imposed by Article 6 of the European Convention on Human Rights, provided that the decisions may be subject to the a posteriori control of a judicial body. It is basically reminiscent of the "privilege of the prior": it is essential to exercise immediate administrative action, control being only a posteriori, hence the essential antinomy of the two forms of repression: the criminal defendant is presumed innocent until appeals are exhausted; the administratively sanctioned person is presumed guilty at the time of the imposition of the sanction and must submit to it immediately, unless he obtains, with difficulty, the benefit of a suspension of execution. The more important the pecuniary sanction is, the less this distinctive feature retains its legitimacy" ${ }^{\prime \prime}$.

\subsection{Non bis in idem?}

Another elusion of the modern protections provided to the criminally charged person by partly administrative repression is the weakening of the non bis in idem rule, according to which two repressive sanctions cannot be applied for the

${ }^{61}$ Emmanuel Rosenfeld, Jean Veil, “Sanctions administratives, sanctions pénales”, 66-67. 
same action. The legislature is, in many contemporary legal systems, competent to decide whether or not it is possible to combine administrative and criminal repressive sanctions. This means that the rule is not considered to be constitutional and to be imposed on the legislature.

It should be noted, however, that the prohibition of the double sanction is enshrined in art. 4 of Protocol 7 to the European Convention on Human Rights. Pursuant to it, "no one shall be liable to be tried or punished again in criminal proceedings under the jurisdiction of the same State for an offence for which he has already been finally acquitted or convicted in accordance with the law and penal procedure of that State".

But the application of the text depends on how the criminal matter is defined, and many states have adopted an organic view of its definition and, consequently, of the administrative one. According to it, a sanction is administrative, and not criminal, if it is established by an administrative body, and the legislature is sovereign in assigning sanctioning powers. It is, for example, the French view ${ }^{62}$, which makes "the French system symptomatic of violating the ne bis in idem rule"63. The Romanian system seems to lean towards the same attitude. For these systems, the non bis in idem rule is one that guarantees first of all the fictionalization of justice, as in Roman law, where it was meant to reduce the number of trials, avoiding that different actions refer to the same acts. The protection of fundamental rights is only a consequence of the protection of the system, not a foundation of it. This view is anti-liberal. The European Court of Human Rights is trying to correct it, as it is trying to correct the attenuation of the procedural guarantees provided by art. 6 of the Convention in the case of charges classified by states as administrative, although they are repressive.

\section{Jurisprudential policy of the European Court of Human Rights to demystify administrative repression}

The European Court of Human Rights is trying to limit administrative repression. Success can only be partial, given the means it possesses. The results are yet remarkable, many states, which initially unreservedly admitted the phenomenon, began to put more and more restrictive conditions on the law-maker, under the influence of the case law of the Strasbourg court.

The first principle of the Court's case-law is that any rule which the legislature classifies as an administrative rule, but which in reality entails a repressive sanction, should be reclassified by the courts as criminal, so that the special protections activated for a person when he is criminally charged may intervene. Only in this way can the protection of rights remain a priority over the exercise of authority. The second principle is that the non bis in idem rule prohibits

${ }^{62}$ Emmanuel Rosenfeld, Jean Veil, "Sanctions administratives, sanctions pénales", 63.

${ }^{63}$ Nicolas Catelan, "Constitution vs CESDH vs UE : ne bis in idem et la répression des opérations d'initié”, Revue de science criminelle et de droit pénal comparé, no. 3 (2016) : 479. 
cumulative repression, even if one of the sanctions is qualified as administrative, if it is actually repressive.

In order to be able to derive these principles from the Convention, the Court had to constructively define the term "criminal" used in the texts. It denied the organic vision adopted by some states, moving the interpretation to the material meaning of the term. It is no longer a question of qualification, but of matter ${ }^{64}$. For a matter to be criminal, it must meet certain criteria, defined by the Court in 1976 in the "Engel" judgment. The Court verifies, using these criteria, whether a "charge", to which the state assigns an administrative character (disciplinary, fiscal, etc.), is in fact related to the "criminal charge" for the purpose of art. 6 of the Convention. For it, "it is first necessary to know whether the provision(s) defining the offence charged belong, according to the legal system of the respondent State, to criminal law, disciplinary law or both concurrently. This however provides no more than a starting point. The indications so afforded have only a formal and relative value and must be examined in the light of the common denominator of the respective legislation of the various Contracting States. The very nature of the offence is a factor of greater import. [...] the State may in principle employ [...] disciplinary law rather than criminal law. In this respect, the Court expresses its agreement with the Government. However, supervision by the Court does not stop there. Such supervision would generally prove to be illusory if it did not also take into consideration the degree of severity of the penalty that the person concerned risks incurring." 65 The application of the criteria is subordinated by the Court to a clear philosophy of the relation between state and law - that of a society "subscribing to the rule of law" 66 , in which, therefore, the rule of law has a teleological value - and of the relation between law and freedom - the one that highlights "the importance attached by the Convention to respect for the physical liberty of the person" ${ }^{67}$. If the sanction supposes "deprivations of liberty liable to be imposed as a punishment" 68 , then it belongs to the "criminal matter", so the accusation that can lead to that sanction is a "criminal charge" within the meaning of art. 6 of the Convention, which implies the need to comply with the guarantees established for the benefit of the person by this text of the Convention. The Court considered as criminal charges qualified under national law as fiscal (Bendedoun v. France, 24 February 1994), some minor traffic offences (Oztürk v. Germany, 21 February 1984), such as withdrawal of driving license points (Malige v. France, 23 September 1998), etc.

As regards cumulative criminal and administrative sanctions, the Strasbourg Court extends, according to the material interpretation summarized above, the scope of the term "criminal" used in art. 4 of Protocol no. 7, which implies that the non bis

${ }^{64}$ Mireille Delmas-Marty, "La matière pénale au sens de la Convention européenne des droits de l'homme, flou du droit pénal", Revue de science criminelle et de droit pénal comparé (1987) : 818 sq.

${ }^{65}$ Case of Engel and Others v. The Netherlands, 8 June 1976, §82, hudoc.echr.coe.int.

${ }^{66}$ Case of Engel and Others v. The Netherlands, 8 June 1976, $§ 82$, hudoc.echr.coe.int.

${ }^{67}$ Case of Engel and Others v. The Netherlands, 8 June 1976, §82, hudoc.echr.coe.int.

${ }^{68}$ Case of Engel and Others v. The Netherlands, 8 June 1976, §82, hudoc.echr.coe.int. 
in idem rule becomes applicable to cumulative sanctions if in reality the administrative sanction is related to the "criminal matter", i.e. it is repressive and dissuasive. The analysis must then focus on the identity of facts. The criterion used by the Court is that of identity of conduct: "[...] the question to be answered is not whether or not the elements of the offences [...] are identical, but whether the offences with which the applicants were charged before [the administrative authority] and before the criminal courts concerned the same conduct" ${ }^{69}$. In other words, it is not about the similarity of the two qualifications, but about the identity of the facts which make the subject-matter of the qualifications. In this way, according to the Court, "if the Contracting States were able at their discretion, by classifying an offence as "regulatory" instead of criminal, to exclude the operation of the fundamental clauses of Articles 6 and 7, the application of these provisions would be subordinated to their sovereign will. A latitude extending thus far might lead to results incompatible with the object and purpose of the Convention." ${ }^{70}$ It is the reason for which the Court invalidated the reserve of Italy that confined the application of art. 4 of Protocol no. 7 and, therefore, of the non bis in idem rule only to procedures and decisions qualified as criminal stricto sensu by the Italian law ${ }^{71}$.

\section{Conclusions}

The conclusion of the above chain of reasoning is obvious. States seek to avoid the control resulting from modern constitutionalism and the guarantees offered by international treaties on human rights - which give them an objective characterby turning regulation and repression under administrative law. They thus violate fundamental rights and freedoms. In order to limit this tendency, the European Court of Human Rights seeks to materially define criminal law and thus make applicable the procedural guarantees granted by the Convention to the defendant during administrative repressive proceedings as well. It attempts to restore administrative law where it belongs. For the Court, a system aimed at guaranteeing rights, i.e. the rule of law as a teleological limit of the sovereign power of the state, is a system whose fundamental structure is based on the distinction between civil law and criminal law, and the latter law is, in the strict sense, exceptional and subsidiary. But the means of action available to the Strasbourg Court cannot remedy the inconsistency of national policies. In the absence of the politicians' awareness of the danger of administrative repression and the transfer of regulatory powers to some authorities that are autonomous from the political controls underlying modern liberal democratic states, it remains for the courts to limit the elusion of our political freedom and violation of our fundamental freedoms by reconfiguring, seemingly without consequences, the basic structure of legal systems, due to the emphasis on a

${ }^{69}$ Case of Grande Stevens v. Italy, 4 March 2014, $\$ 224$; the principles are expressed by the Court in the Case of Serguei Zolotoukhine v. Russia, 10 February 2009.

${ }^{70}$ Case of Oztürk v. Germany, 21 February 1984, §49.

${ }^{71}$ Case of Grande Stevens v. Italy, 4 March 2014, $\S \S 204-11$. 
type of administrative law that favours the state over the citizens and takes the place of criminal law in more and more domains.

To combat this quasi-totalitarian tendency, a legislative classification of the administrative-repressive sanction as criminal is not obviously necessary so that the benefits granted by the European Convention on Human Rights will be applicable. It is the competence of national courts to reconsider it, using the material criterion provided by the case law of the European Court of Human Rights. In this way, the court does not control the norm, but only applies conventional guarantees to safeguard personal freedom according to the regulated "matter". The success of limiting administrative repression and the tendency of the state to elude criminal procedural protections by classifying repression as administrative depends, therefore, on the will of national courts.

\section{Bibliography}

\section{Books}

1. Aron, Raymond. Democraţie şi totalitarism. Bucureşti: All, 2001.

2. Dabin, Jean. Théorie générale du droit. Paris : Dalloz, 1969.

3. David, René, and Jauffret-Spinosi, Camille. Les grands systèmes de droit contemporains. Paris : Dalloz, 2016.

4. Dănişor, Dan Claudiu. Modernitate, liberalism și drepturile omului. Craiova: Simbol, 2018.

5. Dicey, Albert Venn. Introduction to the Study of the Law of the Constitution. London: MacMillian, 1939, $9^{\text {th }}$ edition.

6. Gîrleșteanu, George Liviu. Drept constituțional și instituții politice. București : Universul Juridic, 2012.

7. Gîrleșteanu, George Liviu. Autorități administrative autonome. București : Universul Juridic, 2011.

8. Jouanjan, Olivier. Figures de l'Etat de droit. Le Rechtsstaat dans l'histoire intellectuelle et constitutionnelle de l'Allemagne. Strasbourg: Presses Universitaires de Strasbourg, 2001.

9. Montesquieu. L'Esprit des Lois. Livre XI, Chapitre VI.

10. Rawls, John. Libéralisme politique. Paris : Presses Universitaires de France, Quadrige, 2007.

11. Rawls, John. A Theory of Justice. Cambridge, Massachuttes: The Belknap Press of Harvard University Press, 1971.

12. Rosanvallon, Pierre. La Légitimité démocratique. Impartialité, réflexivité, proximité. Paris: Seuil, 2008.

13. Walzer, Michael. Thick and Thin. The Moral Argument at Home and Abroad. London: University of Notre Dame Press, 1994.

\section{Chapter or other part of an edited book}

1. Pashukanis, Evgeny . "A Course on Soviet Economic Law”. In Selected Writings on Marxism and Law, edited by Piers Beirne and Robert Sharler, 303. London New York: Academic Press, 1980. 
2. Van de Kerchove, Michel. "Pour une étique de l'intervention du droit pénal, entre moralisme et instrumentalisme". In Variations sur l'éthique. Hommage à J. Dabin, edited by Hélène Ackermans, 459. Bruxelles : Presses de l’Université Saint-Louis, 1994.

\section{Translated book}

1. Aristotle. Politics. Translated by Benjamin Jowett. Kitchener: Batouche Books, 1999.

2. Constant, Benjamin. "The Liberty of the Ancients compared with that of the Moderns". In Political Writings. Translated and edited by Biancamaria Fontana. Cambridge: Cambridge University Press.

3. Durkheim, Emile. The Division of Labor In Society. Translated by George Simpson. Illinois: The Free Press of Glencloe, 1960.

\section{E-book}

1. Barret-Kriegel, Blandine. "Jean Bodin et la naissance de l'Etat administrative". In Les chemins de l'État. Paris : Calmann-Lévy, 2014. epub.

2. Cartuyvels, Yves, "Les paradigmes du droit pénal moderne en période «post-moderne»: évolutions et transformations". In Un droit pénal postmoderne? Mise en perspectives des évolutions et ruptures contemporaines. Edited by Michel Massé ; Jean-Paul Jean ; André Giudicelli. Paris: Presses Universitaires de France, 2009. https://dial.uclouvain.be.

\section{Journal article}

1. Catelan, Nicolas. "Constitution vs CESDH vs UE : ne bis in idem et la répression des opérations d'initié”. Revue de science criminelle et de droit pénal comparé, no. 3 (2016) : 467-484.

2. Chevallier, Jacques. "Réflexions sur l'institution des autorités administratives indépendantes". La Semaine juridique, Juris-classeur périodique, no. 30-32 (6 août 1986) : 32-54.

3. Dănișor, Dan Claudiu, and Dănișor, Mădălina Cristina. "Restructurarea justiției și statutul procurorilor". Curierul Judiciar, no. 5 (2018): 245-50.

4. Dănișor, Dan Claudiu, and Dănișor, Mădălina Cristina. "Totalitarianisms and the establishment of objective legal order". Juridical Tribune 10, no. 1 (March 2020): 3655.

5. Dănișor, Dan Claudiu. "The Expert or the People? - On the Justification of Autonomus Authorities”. Revista de Ştiinţe politice/Revues des sciences politique 57 (2018) : 13-24.

6. Delmas-Marty, Mireille. "La matière pénale au sens de la Convention européenne des droits de l'homme, flou du droit pénal". Revue de science criminelle et de droit pénal comparé (1987) : 818 sq.

7. Diaconescu, Horia, and Dănișor, Dan Claudiu. "Poziţia ministerului public faţă de puterea executivă în dreptul unor state vest-europene și în România”. Dreptul, no. 5 (2006) : 102.

8. Gaudemet, Yves, and Gaudemet, Sophie. "Editorial". Henri Capitant Law Review Public Law, Private Law, no. 5 (30 December 2012): § 6. http://www.henricapitant.org/ revue/en/n5. 
9. Jouanjan, Olivier. "Justifier l'injustifiable" (Justifying the unjustifiable). Astérion, no. 4 (2006). http://journals.openedition.org/asterion/643; DOI: https://doi.org/10.4000/ asterion.643

10. Lawson, F.H. "Le droit administratif anglais". Revue internationale de droit comparé 3 , no. 3 (1951): 412-426.

11. Pimentel, Carlos Miguel. "Le sanctuaire vide: la séparation des pouvoirs comme superstition juridique?". Pouvoirs 3, no. 102 (2002): 119-131.

12. Queloz, Nicolas. "Le droit pénal comme ultima ratio: vraiment?". Review of Juridical Sciences, no. 2 (2013): 9-17.

13. Rosenfeld, Emmanuel, and Veil, Jean. "Sanctions administratives, sanctions pénales". Pouvoirs, no. 1 (2009): 61-73.

14. Salas, Denis, and Milburn, Philip. "Les procureurs de la République. De la compétence personnelle à l'identité collective". Archives de politique criminelle 29, no. 1 (2007). DOI:10.3917/apc.029.0095. 